\title{
Towards management of challenges in the innovation process: a case study on the application of the interface assessment tool
}

\author{
Glenn Johansson, Kristina Säfsten \\ Jönköping University \\ e-mail: glenn.johansson@jth.hi.se
}

\begin{abstract}
Product development projects face a broad range of challenges. In this paper, we report the results of a case study in which the so-called Interface assessment tool was used to assess six key challenges in a commercial product development project: 1) market uncertainty, 2) technological uncertainty, 3) product complexity and/or degree of change in product, 4) production complexity and/or degree of change in production, 5) dispersion between technology development and product development, and 6) dispersion between product development and production. Evaluation of the Interface assessment tool indicates consistency with ideal features that tools should have in order to aid in product development. Furthermore, the collective view of the project team members involved in the assessment indicates that the Interface assessment tool offers valuable support for identification of uncertainties, establishment of a joint vision of the project, and minimization of multiple interpretations of the challenges a product development team might face. Consequently, this tool may contribute to sensemaking capability in a product development team.
\end{abstract}

Keywords: innovation, product development, project, challenges, assessment.

\section{Introduction}

Western firms are faced with fierce competition from low cost countries. In order to sustain competitive, the firms need to constantly develop and supply new products to the market. Consequently, innovation capability is a key to success. In this paper innovation refers to "the management of all activities involved in the process of idea generation, technology development, manufacturing and marketing of a new (or improved) product or manufacturing process or equipment." (TROTT, 2005, p. 15).

There is a strong agreement among scholars and practitioners that innovation is complicated and involves a number of challenges that must be handled (KURUMOTO; DE OLIVEIRA; AMARAL, 2012). Some key challenges in the innovation process are complexity, uncertainty, and dispersion (LAKEMOND et al., 2007a). Complexity occurs partly due to differences that exist between the various sub-processes in the innovation process. For example, one factor that complicates the introduction of new technology is that the characteristics of new technology development and product development differ (CLARK; FUJIMOTO, 1991; NOBELIUS, 2004). Whereas technology development often is problem-oriented with fuzzy targets, product development is solution-focused and clearer in terms of market segments. Furthermore, the time horizon of technology development tends to be long-term with unclear completion points, while product development is more short-term with pre- defined deadlines derived from expected market launch. Incorporating new technological solutions in product development thus includes assuring the fit between the new technology and the commercially-oriented product development.

To ensure smooth production start-up it is also vital to assure fit between the product concept and the production process (ADLER, 1995; NOBELIUS, 2004). Product developers thus need to consider production aspects during the design phase and integration between product design engineers and process engineers constitute a vital undertaking in product development projects (ADLER, 1995; SWINK, 1999; VANDEVELDE; VAN DIERDONCK, 2003).

Though innovation management literature provides some guidance on how to manage different challenges within the innovation process, we argue that there is room for enhanced knowledge and support for how to deal with these challenges. Therefore, this paper presents results from a case study in which the Interface assessment tool was applied as an instrument for assessing challenges within a commercial product development project. The Interface assessment tool constitute part of the Interface management method. The method was developed recently in a research project as an aid for product development teams to assess and manage various challenges in the innovation process (LAKEMOND et al., 2007b). The Interface assessment tool 
has appeared in slightly different versions and with diverse terminology (e.g. LAKEMOND et al, 2013), but this paper addresses the original version of the tool.

The remainder of the paper is structured as follows. First, key features of product development support tools are outlined. Then the research approach is presented, followed by a description of the Interface management method that incorporates the Interface assessment tool. The case study and empirical findings are then presented and the paper ends with a discussion and conclusion section.

\section{Key features of product development support tools}

The use of various tools constitute an important ingredient in product development. Different tools might support the specific engineering tasks as well as provide a basis for communication among development team members (CLARK; FUJIMOTO, 1991). For example, early assessments of uncertainties help team members to reach a common understanding of potential challenges faced in a development project. Tools can be of various types: manual or computer-based, quantitative or qualitative, analysis or improvements-directed. The use of various tools does not, however, automatically lead to prosperous product development. Still, in order to support product development efficiency, previous research has indicated that a tool ideally needs to possess certain features as outlined below (HUANG, 1996; NORELL, 1992; RITZÉN, 2000; LINDAHL, 2005):

- Feature $1(\mathrm{~F} 1)$ : addresses a clearly defined area of concern;

- F2: incorporates accepted, non-trivial knowledge concerning the area focused upon;

- F3: avoids unnecessary need for sophistication in modelling and measuring;

- F4: is able to handle data of low quality;

- F5: supports finding weak spots in a design solution;

- F6: supports collaboration and have a learning and developing influence on the users;

- F7: contributes to a systematic work procedure;

- F8: gives a noticeable and preferably measurable effect on project work in the focused area of the product development process;

- F9: is useful in the early phases of product development.

A tool that possesses these ideal features is supposed to enhance efficiency in product development in terms of shorter development cycle times, lower costs, better product quality, improved environmental performance, etc.

\section{Research approach}

The Interface management method, which incorporates the Interface assessment tool, originates from the research project INTERFACE - Interfaces in Industrial Innovation
Processes. The project involved five manufacturing companies and was financially supported by the Swedish Agency for Innovation Systems (VINNOVA). Research was carried out according to a two-phase logic. In the first exploratory phase 10 development projects at five companies were studied in-depth. In the second phase, the Interface management method was developed to support assessment and management of challenges in the innovation process.

The research presented in this paper relies upon a case study in which a product development team used the Interface management assessment tool to assess an ongoing project (EISENHARDT; GRAEBNER, 2007; YIN, 2008). After the assessment session, the appropriateness and applicability of the Interface assessment tool were evaluated. All project members filled out a questionnaire with questions related to appropriateness, coverage of issues, usability, resource efficiency, etc. The responses were given according to an ordinal scale ranging from 1 to 7 , where 1 means 'to a very low degree' and 7 means 'to a very high degree'. The team members were also asked to provide oral feedback regarding the tool and this was captured during a discussion about the tool.

\section{The Interface management method}

The Interface management method consists of two parts: 1) The Interface assessment tool (see Appendix A), and 2) Checklists with guidelines (which is not within the scope of this article). The method is used in a three-step procedure. First, the current situation regarding six product development challenges are assessed. This provides the development team an overview of the project status and helps to identify potential problems. The assessment is carried out as a comparative assessment where challenges in the project is compared to a "typical" product development project within the organisation. The second step focuses on identification of necessary actions to deal with the challenges. Such actions could refer to the inclusion of more personnel resources, increased internal and external communication, or adjustment of the project deadline. The checklists with guidelines act as support for the performance of the actions. On the basis of the identified actions, the third step is to device an action plan that specifies which activities should be carried out, timeframe, responsibilities, etc.

The challenges addressed by the Interface assessment tool are: 1) market uncertainty, 2) technological uncertainty, 3) product complexity and/or degree of change in product, 4) production complexity and/or degree of change in production, 5) dispersion between technology development and product development, and 6) dispersion between product development and production.

Market uncertainty occurs if a new or modified product is directed towards a new market segment (MOSEY, 
2005). Market uncertainty may also occur if the market is unpredictable with constantly changing customer demand and/or price sensitivity. A major source of technology uncertainty is implementation of new (and sometimes non-verified) technology in product development projects (IANSITI, 1995). Product complexity has been defined in different ways; the number of parts involved in the product (MURMANN, 1994), number of product functions (GRIFFIN, 1997) the number of different core technologies (MEYERS; UTTERBACK, 1995), and the interaction between these parts, functions or technologies (NOVAK; EPPINGER, 2001). Also production complexity and the degree of process changes influence the activities in a development project (TERWIESCH; XU, 2004). Another factor that influences product development is separation of activities. This separation may concern geographical but also (inter- and intra-) organizational separation of technology development, product development, and production activities (IANSITI, 1995). Exchange of technical information can be negatively influenced due to cultural, language and time zone differences (SOSA et al., 2002).

To sum up, the Interface management method has been designed to deal with some key challenges that are inherent in a product development project. It helps a product development team to identify and manage these challenges.

\section{Case study and empirical findings}

The study was carried out at company Outdoor that produces a wide variety of products for outdoor use and the products are sold under several brands. Acquisitions have given Outdoor production facilities in Asia and Eastern Europe. It has also lead to the access of a network of local suppliers. The company's strategy is to increase the share of production in some of these facilities as well as purchasing of components from low-cost countries.

Outdoors's investments in product development aims at creating products that combine high performance with a number of other vital aspects such as energy consumption, exhaust emissions, safety, noise levels, ergonomics, userfriendliness, serviceability, and recyclability. The strategy is to develop technology and products that meet or exceed customer expectations as well as current and future legislation minimum standards. Product development is supported by a project model that outlines the different phases of the development process and their associated practices, i.e. the model displays the development process as a stage-gate process (COOPER, 1994). It presents the development process from the early phase when technological and business potentials are identified until the late phase when full-scale production has started. A number of different support tools are associated with the model. The aim of these tools is to support prosperous progress of the development projects. One of these tools is the Interface management method. Outdoor was one of the companies that participated in the development of the Interface management method and the method has been incorporated into the company's project model.

In the case study, the Interface management tool was used to assess the current status of an on-going product development project (project Beta), in which a product was developed for replacement of an existing product. Weight and sales price were, as always, key dimensions of the project goals. Other key dimensions were design and exhaust emission levels. In addition, the project time schedule was very tight in order to be able to launch the product in the market at the correct point of time. The product was developed in Sweden and produced in one of the company's Asian production facilities. The assessment with the Interface assessment tool was carried out when the project had run for some time. The principal design solution had been defined and the project had produced a number of SLS prototypes (Rapid prototyping), which are rapidly produced physical prototypes based on CAD data. Moreover, quotations on tooling and components had been collected from potential suppliers.

The assessment was initiated by the project leader. He considered it to be relevant to check the status of the project regarding which challenges it faced. The assessment was carried out by the core project team members (ULRICH; EPPINGER, 2012), i.e. the project leader, two engineering designers and two laboratory engineers, and was done during a three-hour session. None of the team members had used the Interface assessment tool before, but were given the chance to get familiar with the tool prior to the assessment session. Material that describes the assessment tool and how to use it, as outlined in Outdoors's project model, was made available to the team members a few days before the session.

During the assessment session, we adopted a passive role during the assessment because the purpose was to observe how the team used the Interface assessment tool. However, whenever any questions were raised by the team members regarding the tool we explained how it was supposed to be used.

\subsection{Results from the assessment of the Beta project}

The assessment resulted in that two of the six challenges were given high total scores by the project team. One of these challenges was technological uncertainty. A number of new technological solutions were introduced in the product and some of these solutions had not been tested or applied in previous products. Though calculations and simulations indicated that the solutions would work as expected, the project team members experienced uncertainties regarding how these solutions actually would function in practice. A number of the solutions were also systemic, i.e. strongly 
interrelated to each other. If a solution would not function as expected it would lead to consequences for other parts of the product. The team therefore saw a risk that time consuming redesign activities might be necessary to perform later in the project.

The other challenge that received a high total score was dispersion between product development and production. The development team was located in Sweden, whereas production of the products was to be carried out in Asia. Even though the project team members had been involved in earlier projects where geographical distance was part of the project preconditions, this was considered a vital area that should be monitored carefully. One reason was that the Asian production facility had been acquired fairly recently and therefore routines, forms of cooperation, etc. had not yet been established. In addition, none of the project team members had any experience of working together with that specific facility. Another reason was that the development project involved more actors than a "typical" project. Also development engineers at the Asian facility were involved in the communication with the component suppliers to ensure that the production documentation fitted the suppliers request for information.

The other four challenges were not considered as critical at the point of time when the assessment was carried out. Table 1. shows the outcome of the assessment done by the project team.

The assessment resulted in a number of action points assigned to the project leader. The key action point was to establish continuous communication with the Asian production facility regarding the transfer process between product development and production. The team also specified that one or a few persons from the project team in Sweden should be present when pre-production series were to be produced in the Asian production facility. These two actions were considered to be critical in order to ensure a smooth production start-up and ultimately full-scale production (VANDEVELDE; VAN DIERDONCK, 2003).

\subsection{Evaluation of the Interface assessment tool}

Table 1. Results from the analysis of the Beta project.

\begin{tabular}{|l|c|}
\hline \multicolumn{1}{|c|}{ Challenges } & Total score \\
\hline A. Market uncertainty & 6 \\
\hline B. Technological uncertainty & 11 \\
\hline $\begin{array}{l}\text { C. Product complexity and/or degree of change } \\
\text { in the product }\end{array}$ & 7 \\
\hline $\begin{array}{l}\text { D. Production complexity and/or degree of } \\
\text { change in production }\end{array}$ & 5 \\
\hline $\begin{array}{l}\text { E. Dispersion between technology development } \\
\text { and product development }\end{array}$ & 3 \\
\hline $\begin{array}{l}\text { F. Dispersion between product development } \\
\text { and production }\end{array}$ & 13 \\
\hline
\end{tabular}

As was mentioned earlier, the project team members were asked to provide feedback regarding the Interface assessment tool. Their feedback was captured in a questionnaire as well as through discussions about pros and cons of the tool. The results from the questionnaire is shown in Table 2. Responses were provided according to an ordinal scale ranging from 1 to 7 , where 1 means 'to a very low degree' and 7 means 'to a very high degree'. The questionnaire also included an "open" field, where the participants could give their comments.

The oral comments given by the project team during the discussion clearly overlapped the responses captured in the questionnaire. In general, the team members gave positive feedback about the Interface assessment tool. They thought the tool contributed to a focused discussion regarding highly relevant challenges for a development project. It helped the team members to raise above purely technical issues, which normally are discussed in a project. One of the project team members stated: "The questions are relevant and they guide your thoughts to consider potential problems. The questions help you to 'think outside' the specific field in which you are working". Hence, the tool focused the assessment to the project per se, rather than technical issues related to the product that was developed.

Table 2. Results from the questionnaire.

\begin{tabular}{|l|c|}
\hline \multicolumn{1}{|c|}{ Challenges } & Total score \\
\hline $\begin{array}{l}\text { To which degree does the Interface assessment } \\
\text { tool address relevant areas that are exposed to } \\
\text { uncertainties/risks in a product development project? }\end{array}$ & 6,2 \\
\hline $\begin{array}{l}\text { To which degree contributes the Interface assessment } \\
\text { tool to a systematic work procedure for assessing } \\
\text { uncertainties/risks? }\end{array}$ & 5,8 \\
\hline $\begin{array}{l}\text { To which degree contributes the Interface assessment } \\
\text { tool to a systematic work procedure for managing } \\
\text { uncertainties/risks? }\end{array}$ & 5,6 \\
\hline $\begin{array}{l}\text { To which degree contributes the Interface assessment } \\
\text { tool to a common understanding among the project } \\
\text { team members regarding the project uncertainties/ } \\
\text { risks? }\end{array}$ & 6,8 \\
\hline $\begin{array}{l}\text { To which degree contributes the Interface assessment } \\
\text { tool to cooperation between different competences } \\
\text { in order to manage the project's uncertainties/risks? }\end{array}$ & 5,6 \\
\hline $\begin{array}{l}\text { To which degree contributes the Interface assessment } \\
\text { tool to learning specifically regarding how to manage } \\
\text { risks/uncertainties in a development project? }\end{array}$ & 5,8 \\
\hline $\begin{array}{l}\text { To which degree is it appropriate to use the } \\
\text { Interface assessment tool at various stages during } \\
\text { a development project, i.e. to carry out recurring } \\
\text { assessments with the tool? }\end{array}$ & 6,6 \\
\hline $\begin{array}{l}\text { To which degree is the Interface assessment tool } \\
\text { resource/time efficient for analysing uncertainties/ } \\
\text { risks in a development project? }\end{array}$ & 6,2 \\
\hline & 6,8 \\
\hline
\end{tabular}


One of the product design engineers maintained that " $a$ great deal of discussion is initiated regarding issues that might have been neglected or even avoided. One thinks that these issues are managed later, but now some light are shed on these issues". A test/laboratory engineer added: "I think the questions about the challenges were quite good. They make you think in new ways". The project leader agreed and maintained that the challenges and their related questions were highly relevant. He said: "The questions are really relevant for a development project".

The oral feedback also indicated that preferably a person that is familiar with the Interface assessment tool should be involved when an assessment is carried out; at least when the tool is used for the first time and it is new to the project team. The team claimed that it had been hard to carry out the assessment without having the possibility to get support when questions occurred regarding the tool. This indicates the necessity to specify a person within the organization that can act as an "expert" regarding the tool and its use. Another issue brought to the attention was that the selection of a reference project can be demanding. It can be tricky to define what a "typical" project is, because project team members might not have the same experiences from previous projects.

Still, the collective view of the project team members was that the Interface assessment tool provided valuable support for understanding the status of the project related to some essential product development challenges.

\section{Discussion and conclusion}

As was presented in paragraph 2, tools to be used in product development should have certain features in order to add to development efficiency. The application and evaluation of the Interface assessment tool presented in this paper show that the tool fits well with these features. The tool supported detailed discussions regarding challenges that were considered highly relevant by the product development team. It provided insights into which challenges were potentially most critical. It also provided support for how to manage these challenges, which as illustrated by the case study, resulted in an action plan. It can therefore be claimed that the tool fits with F1 (i.e. addresses a clearly defined area of concern). The Interface assessment tool is firmly based on current scientific knowledge, but also based on the extensive empirical research carried out in the INTERFACE project. It is therefore consistent with F2 (i.e. incorporates accepted, non-trivial knowledge concerning the area focused upon) to a high degree. The tool does not require complex product and production process models or data of high quality in order to be able to produce results from an assessment. Thus, the tool is consistent with F3 (i.e. avoids unnecessary need for sophistication in modelling and measuring) and F4 (i.e. is able to handle data of low quality). The tool does not focus on the product, but the project per se. However, the challenges related to technological uncertainty and product complexity, for example, may help finding weak spots in a design solution. Hence, the tool is also consistent with F5 (i.e. support finding weak spots in a design solution). The responses given in the questionnaire also provide evidence that the tool support collaboration and learning. Thus F6 (i.e. support collaboration and have a learning and developing influence on the users) is confirmed. The feedback from the team members shows that the procedure outlined for using the tool contributes to a systematic work procedure to assess and thereafter manage challenges. F7 (i.e. contribute to a systematic work procedure) is therefore supported. The project team members saw a potential to use the tool at various occasions during a development project. The scoring included in the assessment tool allows comparison of uncertainties/risks related to the challenges at different phases of a development project. It can thus be claimed that F8 is supported (i.e. the tool supports a noticeable and preferably measurable effect on project work in the focused area of the product development process). The fundamental idea of the Interface assessment tool is that it should be used early in a product development project to assess the different challenges. Hence, it definitely fit F9 (i.e. be useful in the early phases of product development) is supported.

On the basis of our findings, we argue that the Interface assessment tool may contribute to the sensemaking capability in a product development team. According to Akgün et al., (2012, p. 474) such sensemaking capability is

"a communicative practice in which people interpret their environment and the surroundings of the project, technology/market-related information, as well as the stimuli through the interaction with others."

In a product development context, such capability relates to internal communication, external communication, information gathering, information classification, building shared mental models, and experimental action (AKGÜN et al., 2012). As the Interface assessment tool relies upon involvement of the entire development team, as well as communication with external actors (e.g. suppliers), it emphasises both internal and external communication in the project. The assessment also indicates whether more information is needed and has to be collected in order to reduce the uncertainties in the project. Gathering more information add to the sensemaking capability if the information is increasingly assimilated and addressed towards team actions. The Interface assessment tool provides a structure to classify the information related to the different challenges, which helps the product development team to be focused in the information collection efforts. The explicit structure of challenges offered by the Interface assessment tool can ignite discussions among the team 
members about project issues that are rarely addressed, as evident in the case study. The emergence of shared mental models of the challenges at hand, as a result of discussions stimulated by the tool, can support the team to better understand the situation and coordinate the appropriate actions (DOUGHERTY et al., 2000).

To sum up, the case study indicates that the Interface assessment tool has the potential to assist a product development team to get better insights into the challenges it faces. The study confirms the initial tests that were carried out in the research project. Hence, we conclude that the Interface assessment tool has the potential to support the identification of uncertainties, establishment of a joint vision of the project, and reduction of the risk of multiple interpretations of the challenges a product development team might face. Uncertainty and ambiguity can thus be minimized in the product development project.

Although the case study presented in this paper shows promising results for the applicability and relevance of the Interface assessment tool, the validity and reliability of the tool must be evaluated in further studies.

\section{Acknowledgements}

The Interface Management method, incorporating the Interface Assessment tool, was developed in collaboration with Dr Nicolette Lakemond and Dr Thomas Magnusson at Linköping university, Sweden. Five manufacturing companies were involved in the development of the method and we appreciate their willingness to share information and knowledge. We would like to express our special thanks to company Outdoor and all team members in the Beta project. The research was financed by VINNOVA, the Swedish Governmental Agency for Innovation Systems.

\section{References}

ADLER, P. Interdepartmental interdependence and coordination: the case of the design/manufacturing interface. Organization Science, v. 6, n. 2, p. 147-167, 1995. http:// dx.doi.org/10.1287/orsc.6.2.147

AKGÜN, A. E. et al. Antecedents and consequences of team sensemaking capability in product development projects. R\&D Management, v. 42, n. 5, p. 474-493, 2012.

CLARK, K. B.; FUJIMOTO, T. Product Development Performance: Strategy, Organization and Management in the World Auto Industry. Boston: Harvard Business School Press, 1991.

COOPER, R. Third-generation new product processes. Journal of Product Innovation Management, v. 11, p. 3-14, 1994. http://dx.doi.org/10.1016/0737-6782(94)90115-5

DOUGHERTY, D. et al. Systems of organizational sensemaking for sustained product innovation. Journal of Engineering and
Technology Management, v. 17, p. 321-355, 2000. http:// dx.doi.org/10.1016/S0923-4748(00)00028-X

EISENHARDT, K.; GRAEBNER, M. Theory building from cases: Opportunities and challenges. Academy of Management Review, v. 50, n. 1, p. 25-32, 2007. http:// dx.doi.org/10.5465/AMJ.2007.24160888

GRIFFIN, A. The effect of project and process characteristics on product development cycle time. Journal of Marketing Research, v. 34, n. 1, p. 24-35, 1997. http://dx.doi. org $/ 10.2307 / 3152062$

HUANG, G. Q. Design for X - Concurrent Engineering Imperatives. London: Chapman \& Hall, 1996. cap. 1: Introduction.

IANSITI, M. Technology development and integration: an empirical study of the interaction between applied science and product development. IEEE Transactions on Engineering Management, v. 42, n. 3, p. 259-69, 1995. http://dx.doi.org/10.1109/17.403744

KURUMOTO, J. S.; DE OLIVEIRA, M. G.; AMARAL, D. C. Technology-product integration in SMEs: The unclear separation between the technology and product development. Product: Management \& Development, v. 10, n. 2, p. 95-103, 2012.

LAKEMOND, N. et al. A model for managing interfaces between technology development, product development and production. In: R\&D MANAGEMENT CONFERENCE, 2007, Bremen. Proceedings... Bremen, 2007a. CD-ROM.

LAKEMOND, N. et al. Interfaces between technology development, product development and production: Critical factors and a conceptual model. International Journal of Technology Intelligence and Planning, v. 3, n. 4, p. 317 330, 2007b. http://dx.doi.org/10.1504/IJTIP.2007.016303

LAKEMOND, N. et al. Assessing interface challenges in product development projects. Research-Technology Management, v. 56, n. 1, p. 40-48, 2013. http://dx.doi. org/10.5437/08956308X5505078

LINDAHL, M. Engineering designers' requirements on Design for Environment methods and tools. 2005. Thesis (Doctorate)-Royal Institute of Technology, Stockholm, 2005.

MEYERS M. H.; UTTERBACK, J. M. Product development cycle time and commercial success. IEEE Transactions on Engineering Management, v. 42, n. 4, p. 297-304, 1995. http://dx.doi.org/10.1109/17.482080

MOSEY, S. Understanding new-to-market product development in SMEs. International Journal of Operations \& Production Management, v. 25, n. 2, p. 114-130, 2005. http://dx.doi. org/10.1108/01443570510576994

MURMANN, P. A. Expected development time reductions in the German mechanical engineering industry. Journal of 
Product Innovation Management, v. 11, n. 3, p. 236-252, 1994. http://dx.doi.org/10.1016/0737-6782(94)90006-X

NOBELIUS, D. Linking product development to applied research: transfer experiences from an automotive company. Technovation, v. 24, p. 321-34, 2004. http://dx.doi. org/10.1016/S0166-4972(02)00073-1

NORELL, M. Stödmetoder och samverkan i produktutveckling. (Advisory tools and co-operation in product development). 1992. Thesis (Doctorate)-Royal Institute of Technology, Stockholm, 1992. In swedish.

NOVAK, S.; EPPINGER, S. D. Sourcing by design: product complexity and the supply chain. Management Science, v. 47, n. 1, p. 189-204, 2001. http://dx.doi.org/10.1287/ mnsc.47.1.189.10662

RITZÉN, S. Integrating environmental aspects into product development - Proactive measures. 2000. Thesis (Doctorate)Royal Institute of Technology, Stockholm, 2000.

SOSA, M. E. et al. Factors that Influence Technical Communication in Distributed Product Development: An Empirical Study in the Telecommunications Industry. IEEE
Transactions on Engineering Management, v. 49, n. 1, p. 45-58, 2002. http://dx.doi.org/10.1109/17.985747

SWINK, M. Threats to new product manufacturability and the effects of development team integration processes. Journal of Operations Management, v. 17, p. 691-709, 1999. http:// dx.doi.org/10.1016/S0272-6963(99)00027-3

TERWIESCH, C.; XU, Y. The copy-exactly ramp-up strategy: trading-off learning with process change. IEEE Transactions on Engineering Management, v. 51, n. 1, p. 70-84, 2004. http://dx.doi.org/10.1109/TEM.2003.822465

TROTT, P. Innovation management and new product development. 3rd ed. Prentice Hall, 2005

ULRICH, K.; EPPINGER, S. Product Design and Development. 5th ed. McGraw-Hill, 2012.

VANDEVELDE, A.; VAN DIERDONCK, R. Managing the design-manufacturing interface. International Journal of Operations \& Production Management, v. 23, n. 11, p. 13261348, 2003. http://dx.doi.org/10.1108/01443570310501871

YIN, R. Case study research: Design and methods. Sage Publications Inc., 2008. 
Appendix A. The Interface assessment tool presented here is the original version and it is this version that was tested and evaluated within the case study.

The Interface assessment tool

The assessment is performed on the following scale:

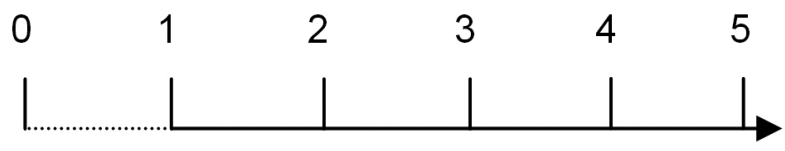

The assessment is performed in comparison with the chosen reference project and the following scale applies:

\begin{tabular}{|l|l|}
\hline 0 & To a lesser extent than the reference project or not relevant \\
\hline 1 & In correspondence with the reference project \\
\hline 5 & To a much higher extent than the reference project \\
\hline
\end{tabular}

- A. Market uncertainty

\begin{tabular}{|l|l|l|}
\hline \multicolumn{1}{|c|}{ Market uncertainty } & Score \\
\hline A.1 & It is difficult to predict the sales volume. & \\
\hline A.2 & It is difficult to define/capture the customer needs and/or product requirements are indistinct. & \\
\hline A.3 & The product is targeted for markets/customers new to the company. & \\
\hline A.4 & The product's life cycle is short and/or the deadline for market introduction is critical. & \\
\hline
\end{tabular}

- B. Technological uncertainty

\begin{tabular}{|c|c|c|}
\hline \multicolumn{2}{|r|}{ Technological uncertainty } & \multirow[t]{2}{*}{ Score } \\
\hline B.1 & The product includes new technological solutions that have not been verified in the specific product type. & \\
\hline B.2 & The product depends entirely on the application of new technology, i.e. there are no backup alternatives. & \\
\hline B. 3 & A large part of the product is affected by the new technology. & \\
\hline B.4 & The project group is not used to work with new technologies in the project. & \\
\hline & Total score & \\
\hline
\end{tabular}

- C. Product complexity and/or degree of change in the product

\begin{tabular}{|c|c|c|}
\hline \multicolumn{2}{|r|}{ Product complexity and/or degree of change of the product } & \multirow[t]{2}{*}{ Score } \\
\hline C.1 & The product includes a variety of different technologies (electronics, mechanics, material, software, etc.) & \\
\hline C. 2 & The product consists of a large number of different components that are affected and/or changed. & \\
\hline C. 3 & Many dependencies exist between the components in the product that are affected and/or changed. & \\
\hline C. 4 & Solutions developed in the project are/will be used in several different products. & \\
\hline & Total score & \\
\hline
\end{tabular}

- D. Production complexity and/or degree of change in production

\begin{tabular}{|c|c|c|}
\hline \multicolumn{2}{|r|}{ Production complexity and/or degree of change in production } & \multirow[t]{2}{*}{ Score } \\
\hline D.1 & The production system contains difficult process steps and/or high demands on tolerances, accuracy etc. & \\
\hline D.2 & The degree of automation changes in the production system. & \\
\hline D.3 & The production includes new production technology/equipment. & \\
\hline D.4 & The production system includes new layout/production set-up. & \\
\hline & Total score & \\
\hline
\end{tabular}


Appendix A. Continued...

- E. Dispersion between technology development and product development

\begin{tabular}{|c|c|c|}
\hline \multicolumn{2}{|r|}{ Dispersion between technology development and product development } & Score \\
\hline E.1 & The project group is localized far away from the technology development location. & \\
\hline E.2 & $\begin{array}{l}\text { There are great cultural differences between the actors involved in technology development and those } \\
\text { involved in product development. }\end{array}$ & \\
\hline E.3 & Many different actors are involved in technology development and product development. & \\
\hline E.4 & $\begin{array}{l}\text { The development project needs to collaborate with persons working with technology development who } \\
\text { are previously unknown to the project members. }\end{array}$ & \\
\hline & Total score & \\
\hline
\end{tabular}

- F. Dispersion between product development and production

\begin{tabular}{|c|l|c|}
\hline \multicolumn{1}{|c|}{ Dispersion between product development and production } & Score \\
\hline F.1 & Production is localized far away from the product development project. & \\
\hline F.2 & $\begin{array}{l}\text { There are great cultural differences between the actors involved in product development and those } \\
\text { involved in production. }\end{array}$ & \\
\hline F.3 & Many different actors are involved in product development and production. & Total score \\
\hline F.4 & $\begin{array}{l}\text { The development project needs to collaborate with persons in production who are previously unknown } \\
\text { to the project members. }\end{array}$ & \\
\hline
\end{tabular}

For each challenge, the total score is calculated. Based on the result the following actions are recommended:

- Total score $\leq 6$ : No special attention is needed.

- Total score 7-11 or 3 for any of the items: Active monitoring is necessary, take some preventive managerial actions.

- Total score $\geq 12$ or 4 or 5 for any of the items: Take preventive managerial actions. 